\title{
Design and Build a Photo Studio Marketplace Using The Codeigniter Framework
}

\author{
Dony Novaliendry ${ }^{*}$, Nazifa Dwi Putri ${ }^{2}$ \\ 1,2 Faculty of Engineering, Universitas Negeri Padang, Padang, Indonesia \\ *Corresponding Author: dony.novaliendry@ft.unp.ac.id
}

\begin{abstract}
INTISARI
Marketplace ini menyediakan pengelolaan pembayaran dan pemesanan paket-paket photo. Kemudian konsumen akan melakukan pemesanan paket photo yang tersedia di beberapa studio photo. Harga yang sudah ditetapkan pada marketplace tidak bisa ditawar lagi. Setelah itu pihak studio photo akan mengelola pesanan konsumen tersebut. Tujuan tugas akhir ini adalah untuk menghasilkan marketplace studio photo di Kota Padang agar pelaku jasa daapat dengan mudah memasarkan jasanya dan agar konsumen mudah mencari informasi dari banyak studio photo mengenai kualitas dan harga yang ditawarkan studio photo. Rancang bangun marketplace ini dibangun berbasis web menggunakan framework codeIgniter. Aplikasi ini dikembangkan dengan metode waterfall model. Hasilnya, dapat memeberikan pelayanan yang cepat bagi konsumen karena pemesanan dan pembayarannya bisa dilakukan secara online.
\end{abstract}

Kata kunci: Marketplace, Promosi, Framework CodeIgniter, Pemesanan.

\begin{abstract}
This marketplace provides payment management and ordering of photo packages. Then the consumer will order a photo package that is available in several photo studios. Prices that have been set on the marketplace are non-negotiable. After that, the photo studio will manage customer orders. The purpose of this final project is to produce a photo studio marketplace in the city of Padang so that service actors can easily market their services and so that consumers can easily find information from many photo studios regarding the quality and price offered by photo studios. The design of this marketplace is built on a web basis using the Codelgniter framework. This application was developed with the waterfall model method. As a result, it can provide fast service for consumers because ordering and payment can be made online.
\end{abstract}

Keywords: Marketplace, Promotion, Framework CodeIgniter, Booking.

\section{INTRODUCTION}

The marketplace is a new business model that develops in line with the rapid development of information technology infrastructure[1]. This marketplace is designed to minimize complex business processes to create efficiency and effectiveness[2]. The indicator of marketplace effectiveness is determined by the market place's ability to facilitate transactions, bring together sellers and buyers and provide infrastructure. Meanwhile, the efficiency indicator relates to the short time and costs provided by the marketplace[3].

Photo Studio is a service sector that offers photography services to capture certain moments in photos and videos, such as weddings, pre- wedding, birthdays, graduations, family, etc[4], [5]. Concerning the world of services that makes the relationship between service actors and consumers easier and easier, there is still little use of technology in marketing and photo studio service searches, perhaps only limited to using social media such as Instagram and WhatsApp and Facebook[6].

For now, it is not easy to find photography services in photo studios with good quality and affordable prices, and we have to survey many photo studios in advance because it takes quite a long time. After all, there are still few systems that provide detailed information about many of these photo studios. Besides, from the perspective of service actors, it is still difficult to market their services because information media block them. 
Even though there is only marketing, it does not include ordering and payment by the system.

Based on the results of surveys through interviews conducted at several photo studios in Padang City, it can be seen that photo studios promote services by distributing brochures, billboards and using social media in the form of Instagram, WhatsApp and Facebook so that the scope for obtaining information is limited. And promotions that are carried out do not attract consumer interest because consumers do not get complete information about photo studios' services. The following is a table of the results of a survey conducted in 4 photo studios in Padang City:

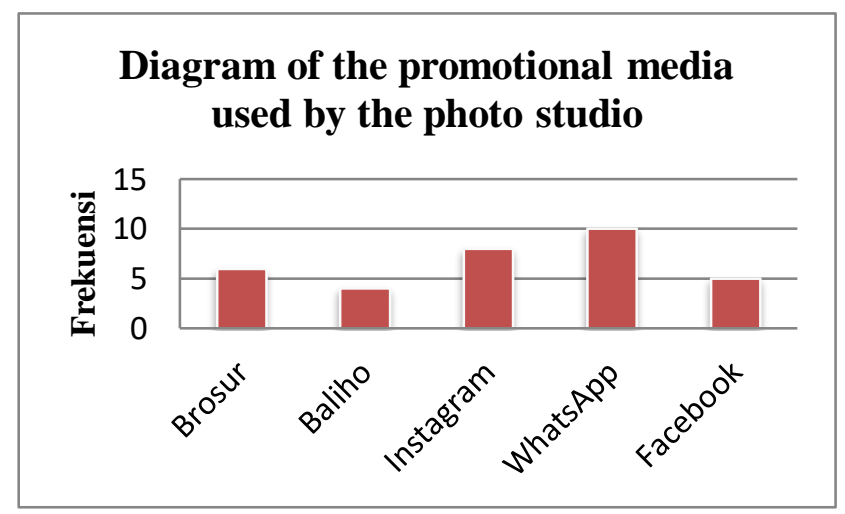

Figure 1. Promotion Media Diagram Used by Photo Studio in Padang City

The purpose of building this photo studio marketplace is to easily market their services so that consumers can easily find information from many photo studios regarding the quality and price offered by photo studios. In the marketplace application that will be created, the marketplace provides payment and order management. Then consumers will order photo packages available in several photo studios through the marketplace. Prices that have been set on the marketplace are non-negotiable. After that, the photo studio will manage customer orders.

This marketplace application's development uses the Unified Modeling Language (UML) model with the waterfall model method and the PHP programming language using a CodeIgniter framework. Unified Modeling Language (UML) is a modelling language for object-oriented paradigmatic systems or software. Modelling is used to simplify complex problems to be easier to understand and learn[7]. Some literature states that UML provides nine types of diagrams. Others mention eight because several diagrams are combined. For example, communication diagrams, sequence diagrams, and time diagrams are combined into interaction diagrams [8].

PHP is a programming language used to create website-based applications. As an application, the website should be dynamic and interactive. Having a dynamic nature means that the website can change its content according to certain conditions (for example, displaying different products for each visitor). Interactive means the website can provide feedback for the user (for example, displaying product search results) [8][9].

The framework is a collection of instructions collected in classes and functions with their respective functions to make it easier for developers to call them without writing the same program syntax repeatedly and saving time [10][11]. Codeigniter is a PHP framework that is open source and uses the MVC (model, view, controller) method to make it easier for developers or programmers to build a web-based application without creating it from scratch [12], [13].

With this concept, PHP code, Mysql, Javascript and CSS queries can be separated from each other so that the file size becomes smaller and easier for future repairs or maintenance.

\section{METHOD}

\section{Research Method}

The software development method used is the waterfall model. In the waterfall model, several main stages described software development activities[14][15].

a. Needs Analysis

In this stage, the data collection of needs is collected completely, and the needs that have to be fulfilled are analyzed and defined by the application.

b. System Design

After the needs data have been successfully collected and analyzed, the design of the system that will be made is conducted.

c. Implementation

In this stage, the program design will be translated into codes by using the determined program language.

d. System Testing

After the program has been completed, it will be tested as a whole.

e. Maintenance

Maintenance can take the form of adjustments or changes due to the adaptation to the real situation. 


\section{Running System Analysis}

a. System Analysis

Analyzing the current system is an important thing that must be done before designing a new system. By analyzing the current system, it can be seen the system's weaknesses to design a new, better system.

b. Problem analysis

The problems faced in several photo studios in Padang include promoting photography services in photo studios by distributing brochures, Instagram, WhatsApp and Facebook so that the scope for obtaining information is limited. And promotions that are carried out are less attractive to consumers because consumers do not get complete information about the photo studio's services.

Also, the order and payment process still uses manual methods. Namely, consumers come directly to the photo studio location. Another problem is the absence of clear recording of order data, payment data and customer data.

c. User Analysis

The parties involved in the design of the photo studio marketplace in the city of Padang are:

1. Master Admin

Master Admin is a user who manages the website and has full access to the system.

2. Studio Admin

Studio admin is the user who manages the website per photo studio. Studio admin can manage package type data, manage packages, manage orders and view and print reports on the system.

\section{Customer}

Customers are people who have registered via the website to have an account to log in and order photography services through the photo studio marketplace in Padang City.

d. Document Analysis

1. Input Document Analysis

Input documents include all forms of inputting user data, package type data, package data, photo studio data and customer data into the photo studio marketplace in Padang City. For more details, the input document can be seen in the table below:

\begin{tabular}{|c|c|c|c|}
\hline No & Document Name & $\begin{array}{l}\text { Related } \\
\text { User }\end{array}$ & Document Contents \\
\hline 1 & User Data & $\begin{array}{l}\text { Master } \\
\text { Admin }\end{array}$ & $\begin{array}{l}\text { data users who have } \\
\text { access to the system }\end{array}$ \\
\hline 2 & Packet type Data & Admin & $\begin{array}{l}\text { the types of packages } \\
\text { provided in each photo } \\
\text { studio }\end{array}$ \\
\hline 3 & Packet Data & Admin & $\begin{array}{l}\text { packet data provided } \\
\text { based on existing package } \\
\text { types }\end{array}$ \\
\hline 4 & Bank Data & Admin & $\begin{array}{l}\text { photo studio bank data } \\
\text { which is useful for bank } \\
\text { transfers when there is } \\
\text { an order for services }\end{array}$ \\
\hline 5 & Customer Data & $\begin{array}{l}\text { Master } \\
\text { Admin }\end{array}$ & $\begin{array}{l}\text { contains biodata of } \\
\text { customers who have } \\
\text { registered }\end{array}$ \\
\hline 6 & Order Data & Admin & $\begin{array}{l}\text { service order data from } \\
\text { all customers }\end{array}$ \\
\hline 7 & Photo Studio Data & $\begin{array}{l}\text { Master } \\
\text { Admin }\end{array}$ & $\begin{array}{l}\text { Contains photo studio } \\
\text { data registered in the } \\
\text { system }\end{array}$ \\
\hline
\end{tabular}

2. Output Document Analysis

The output document is a form on the system to display the required information or reports, namely:

\begin{tabular}{ccll}
\multicolumn{2}{l}{ Table 2 Output Document Analysis } & \\
\hline No & Document Name & $\begin{array}{l}\text { Related } \\
\text { User }\end{array}$ & Document Contents \\
\hline 1 & Order data report & $\begin{array}{l}\text { Admin } \\
\text { Studio }\end{array}$ & Customer data reports \\
2 & Proof of booking & Customer & Proof of booking \\
3 & Transaction report & $\begin{array}{l}\text { Admin } \\
\text { Studio }\end{array}$ & $\begin{array}{l}\text { Payment transaction } \\
\text { report }\end{array}$ \\
\hline
\end{tabular}

e. Service Order Process Analysis

Analyzing the service ordering process is an important thing that must be done to determine the steps taken by customers to order photography services at the photo studio marketplace in Padang City. By analyzing service orders, we can find out the system's weaknesses and then design a new, better system.

Describe the problems faced in several photo studios in Padang City by providing the expected solutions and goals. For more details, see table 5 below: 


\begin{tabular}{lll}
\multicolumn{2}{c}{ Table 3 Problems and Solution } & \\
\hline No & Problem & Solution \\
\hline 1 & $\begin{array}{l}\text { The process of project } \\
\text { management, promotion, } \\
\text { ordering services still uses a } \\
\text { manual system }\end{array}$ & $\begin{array}{l}\text { It is hoped that a photo } \\
\text { studio marketplace in the } \\
\text { city of Padang can help } \\
\text { photo studios in project } \\
\text { management, assist in } \\
\text { promotions, make it easier } \\
\text { for customers to order } \\
\text { services. }\end{array}$ \\
& $\begin{array}{l}\text { The promotion process in } \\
\text { several photo studios in } \\
\text { Padang City currently still } \\
\text { involves distributing } \\
\text { brochures, installing } \\
\text { billboards, and social media } \\
\text { such as Instagram, } \\
\text { WhatsApp and Facebook. }\end{array}$ & $\begin{array}{l}\text { It is hoped that the presence } \\
\text { of a photo studio } \\
\text { marketplace in the city of } \\
\text { Padang can increase photo } \\
\text { studios' promotion to } \\
\text { convince customers to place } \\
\text { orders for photography } \\
\text { services. }\end{array}$ \\
\hline
\end{tabular}

\section{f. Proposed Flowmap}

Flow maps describe any activity that is running, describe the visible flow, explain data and information relationships with parts of the activity, data flow (in the form of input and output documents). The flowmap proposed to build a photo studio marketplace in Padang City is as follows:

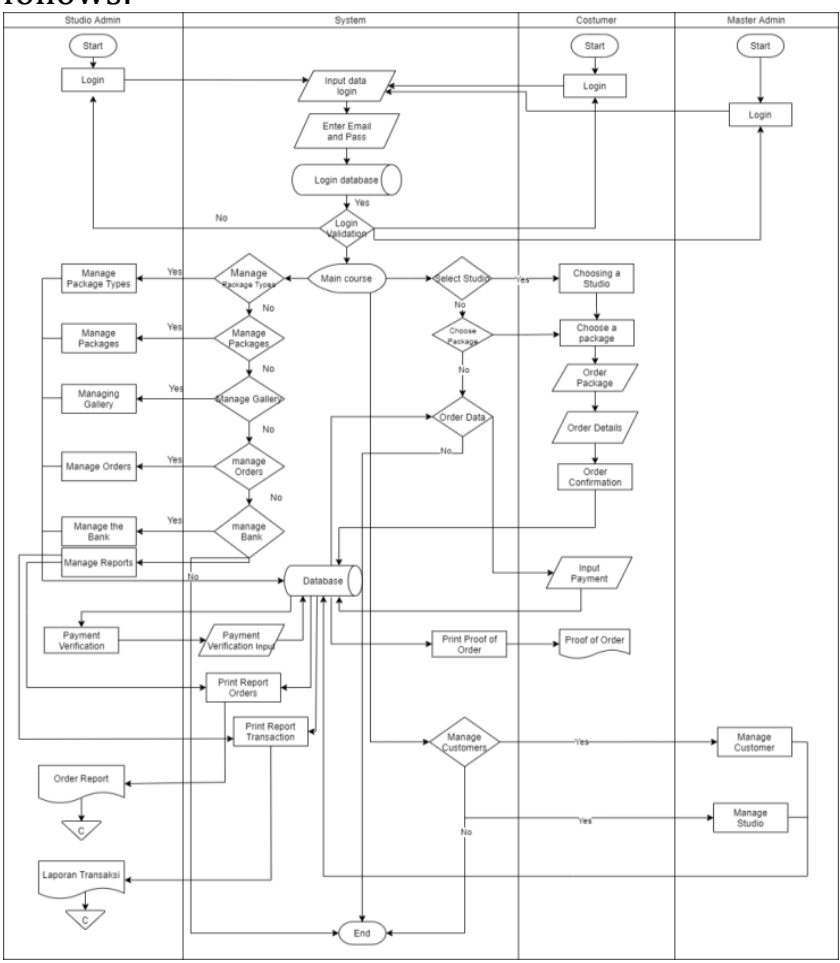

Figure 2. Running Services Flowmap Marketplace In Padang City

\section{System Planning}

At this stage is implementing a new system to improve the old system. By implementing a new system, it is hoped that the author will analyze the information needs, namely the design of a photo studio marketplace in the city of Padang using a CodeIgniter framework. This design requires a major element in designing a new system.

\section{Context Diagram}

A Context Diagram is a flow diagram that contains the highest overall system process. Context Diagram illustrates the relationship of all system input and output.

The following is a Context Diagram for the Design of a Photo Studio Marketplace in the City of Padang:

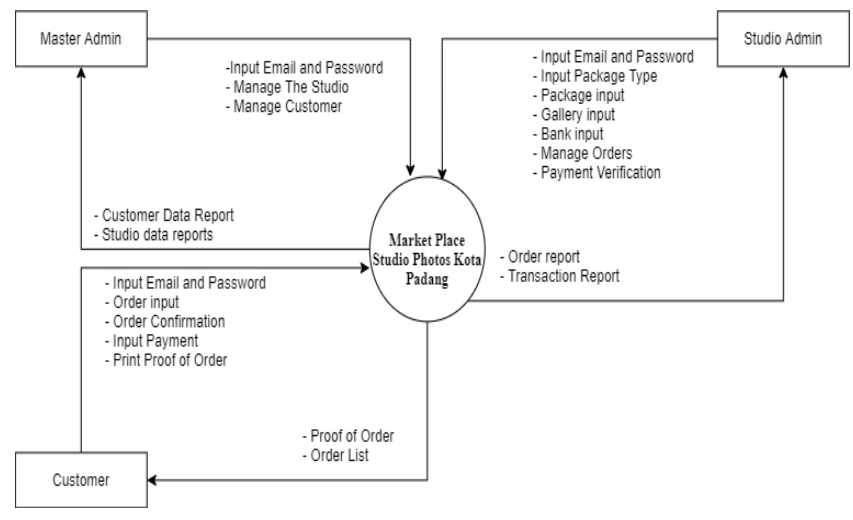

Figure 3. Context Diagram Marketplace In Padang City

The forms of the entity's involvement are:

The admin part of the package into the system, then the information system produces the available packet data. Customers place orders for packages and get proof of order and confirm payment. Admin can see order data through the photo studio marketplace.

2. Use Case Diagram

Use Case Diagrams are diagrams that show a set of use cases and actors (a special type of class) [5][11]. This diagram has two functions: defining what features the system should provide and stating the system's nature from the user's point of view.

Use Case describes an interaction between one or more actors with the information system to be created. All actors have their respective duties in the system related to each other and most of the activities of the actors' activities require the actor to first log into the system.

The following is the design of a use case diagram for the Photo studio Marketplace Design in Padang City: 


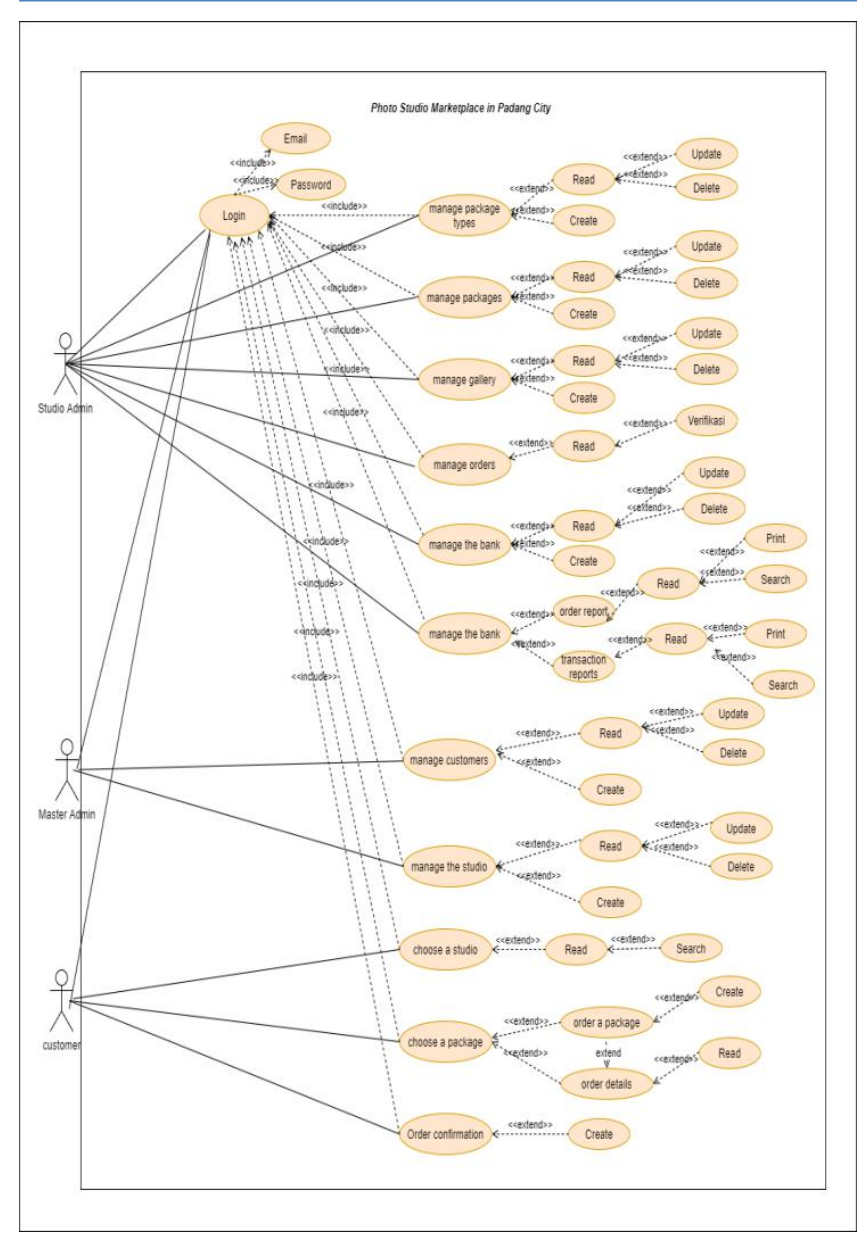

Figure 4. Use Case Diagram Marketplace In Padang City

Figure 4 above explains that the Photo studio Marketplace Design in Padang City, which will be built, involves three actors, namely:

a. Master Admin

Master Admin is a user who has full access rights to the system. Where the master admin access to the system is as follows:

\section{View customer data}

Where the master admin can see customer data, who registered through the photo studio marketplace.

2. Manage the studio

Where the master admin can manage photo studio data that registers through the photo studio marketplace.

b. Studio Admin

Studio admin is a photo studio user who has full access rights to the registered photo studio. Where the studio admin's access to the system is as follows:
1. Manage bank data

Where the admin can add data, edit and delete bank data.

2. Manage package types

Where admin can add data, edit and delete package type data.

3. Manage packet data

Where admin can add data, edit and delete packet data.

4. Manage gallery

Where the admin can add galleries, edit and delete galleries.

5. Manage reports

Where the admin can view, search and print the required reports.

c. Customer.

Customers are users who have registered and have a username and password to log in. After logging in, the customer can place an order for services and confirm payment for the order.

\section{Database Design}

Database design is the stage for designing the data storage structure that the application needs:

a. Entity Relationship Diagram (ERD)

Entity Relationship Diagram is a technique used to model an organisation's data requirements, usually by system analysts in the requirements analysis stage of a system development project [7].

ERD from the design of the photo studio marketplace in Padang City can be seen in the following image: 


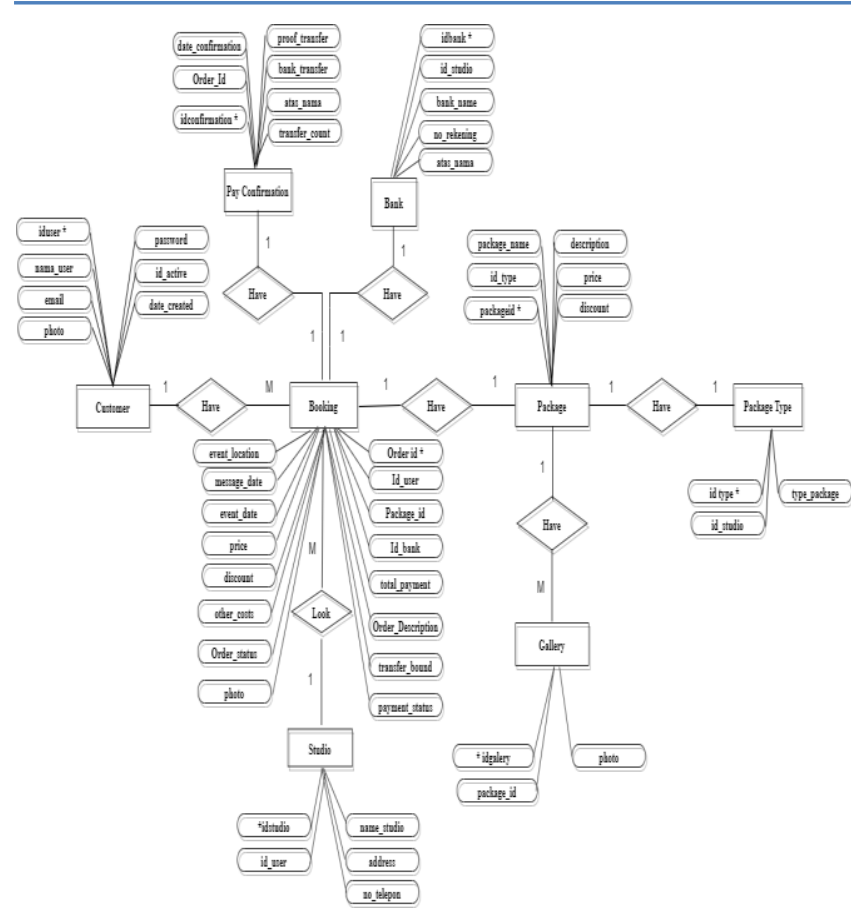

Figure 6. Entity Relationship Diagram (ERD) design of the Photo Studio marketplace in Padang City

\section{Interface Design}

This interface design aims to design the interface that will be used on the system to be built. The interface design (display) must be comfortable to see, easy to use, unambiguous and so on.

a. Main Page Design

The main page view is the display that will appear the first time you open the web page address. The main page interface design is shown as follows:

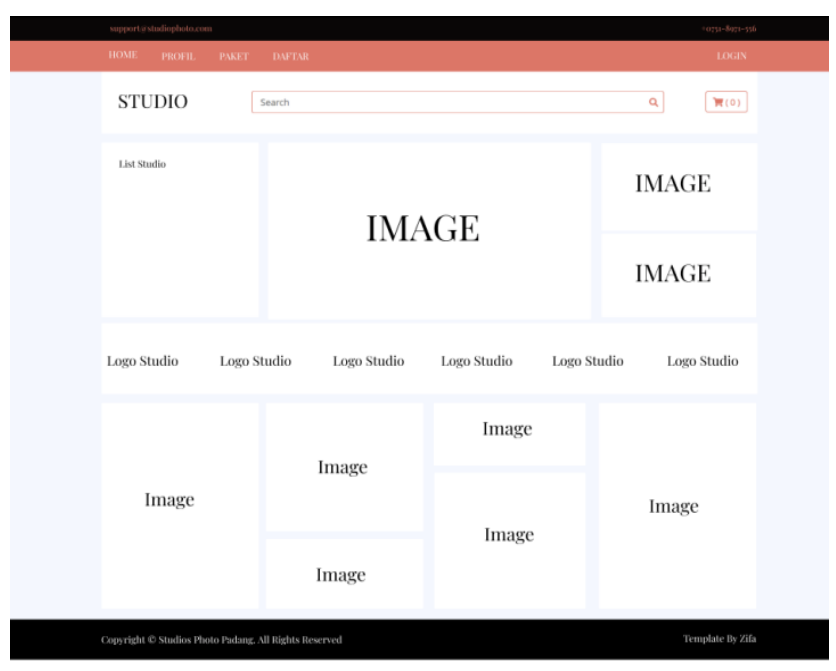

Figure 7. Main Page Design

\section{b. Login Display Design}

The login display design is a display that will be used as a gate to access or enter into the system at large. The login display design is shown as follows:

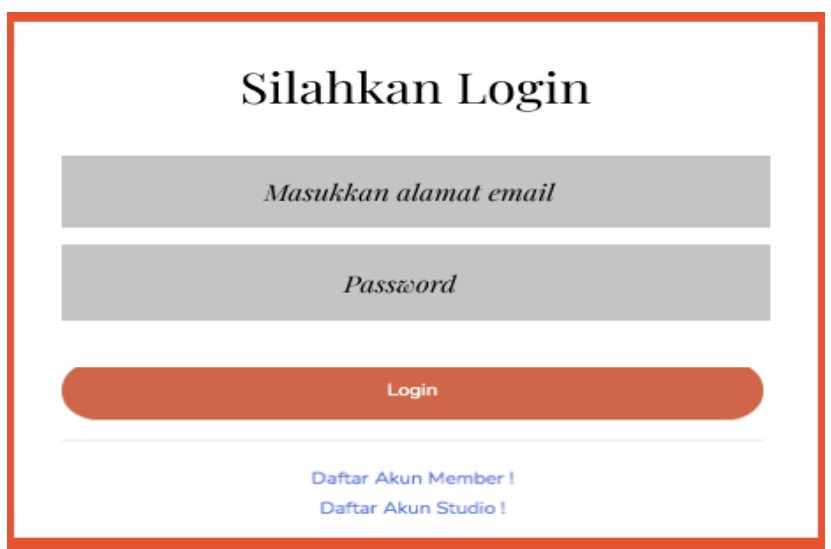

Figure 8. Login Display Design

The password input form is made hidden for the text input from the login display design so that the entered password is not known by others when inputting it.

c. Checkout Page Design

The order checkout page display is the display that will appear when the customer clicks the checkout button and continues to the shopping cart. The order confirmation page interface design is shown as follows:

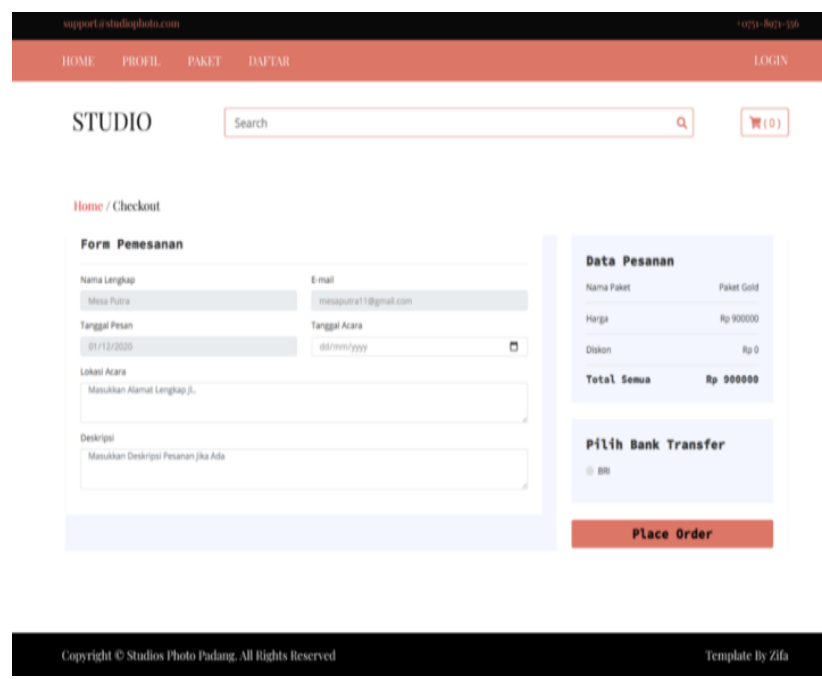

Figure 9. Checkout Page Design 


\section{RESULTS AND DISCUSSION}

Implementation activities are accompanied by system testing. This aims to determine the errors that exist when typing program code to be corrected and display the work of the system that has been made.

\section{Main page}

This page is the main page that appears when a user opens the photo studio marketplace page in Padang City. The main page display is shown in Figure below:

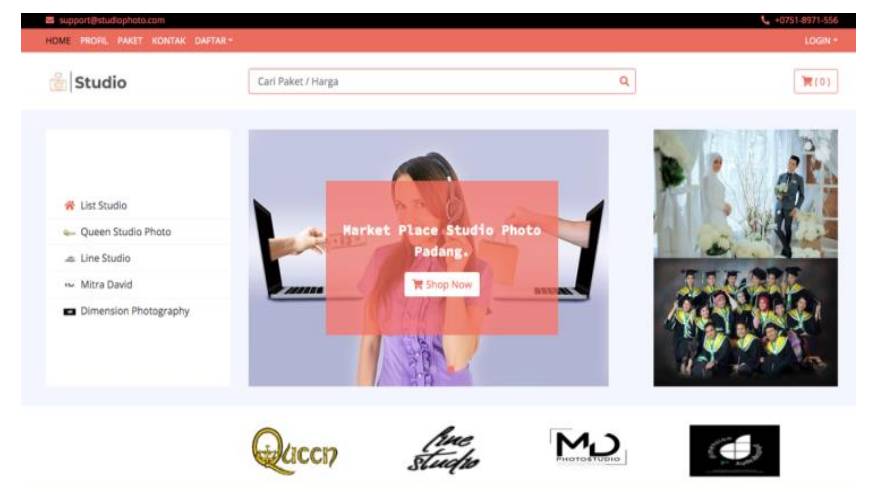

Figure 10. The main page of Photo Studio Marketplace in Padang City

\section{Member List page}

This page is a page that users use to register as members in the photo studio marketplace in Padang. The member list page display is shown in Figure 24 below:

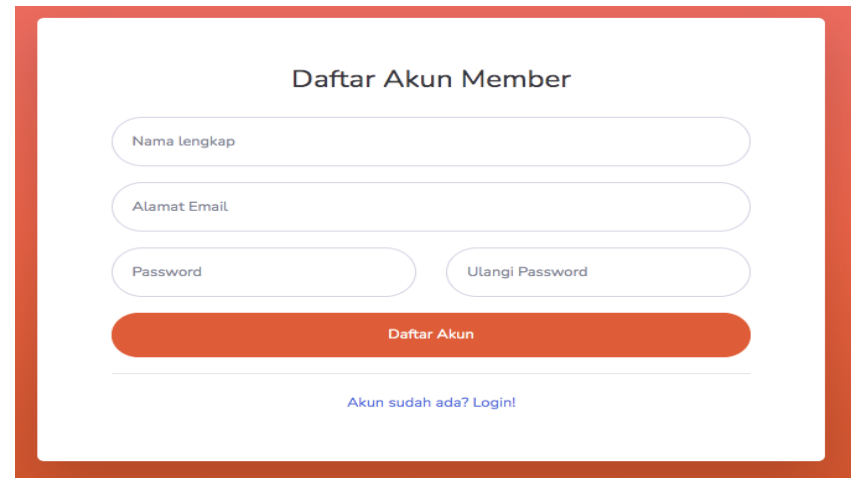

Figure 11. Member List Page

After a member registers and clicks the account register button, the system will automatically send a message to the registered member email to verify that the member's account is active. Then the member clicks the active button. If the verification is successful, the member will be thrown to the login page. For more details, it can be seen in Figure 4 below:

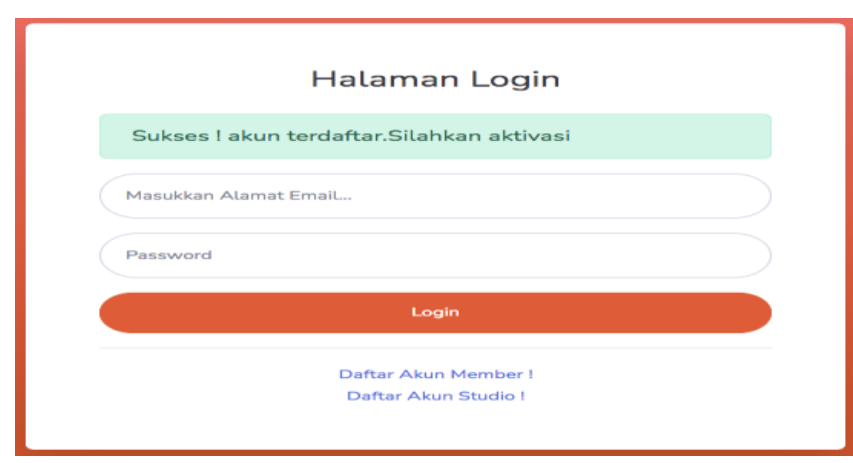

Figure 12. Account Verification Notification

\section{Master Admin Main Page}

The master admin main page is the page that first appears when the master admin successfully logs in to the Padang City Photo Studio Marketplace. For more details, it can be seen in Figure 7 below:
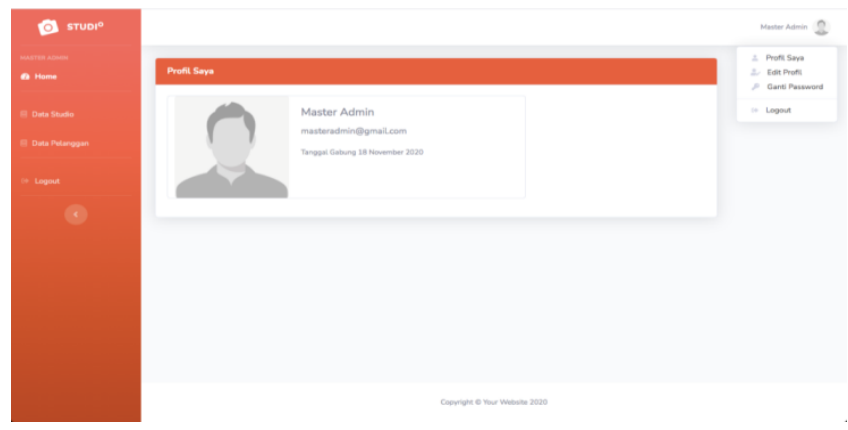

Figure 13. Master Admin Main Page

Based on Figure 7, this page displays menu options, namely home, studio data, customer data, edit profiles and change passwords.

a. Data Studio menu
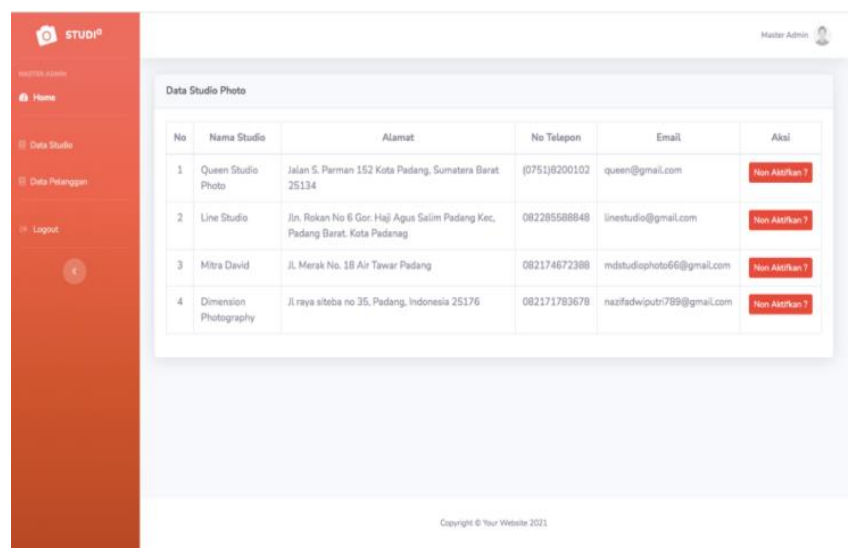

Figure 14. Data Studio Menu

\section{b. Customer Data Menu}

The customer data menu is a menu used to display all customers who have registered for an account through the photo studio marketplace in 
Padang City. For more details, it can be seen in Figure 9 below:
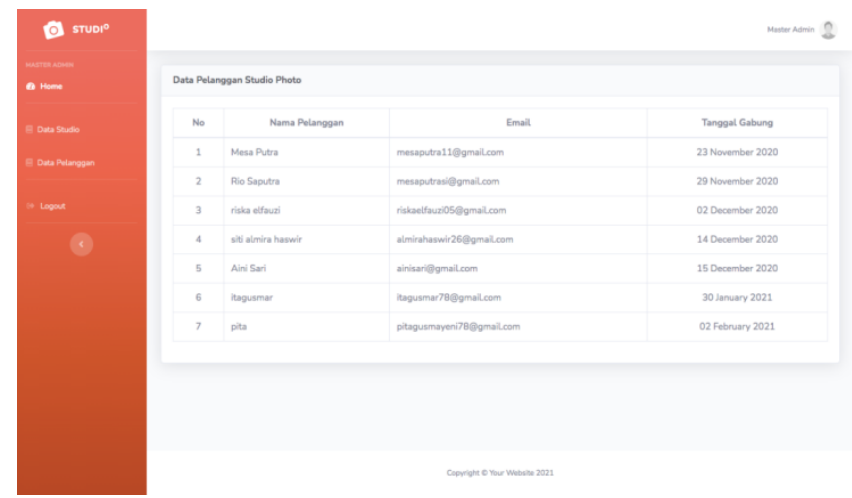

Figure 15. Customer Data Menu

\section{The Studio Admin Main page}

The main studio admin page is the first page to appear when the studio admin successfully logs in to the photo studio marketplace in Padang City. For more details, it can be seen in Figure 12 below:

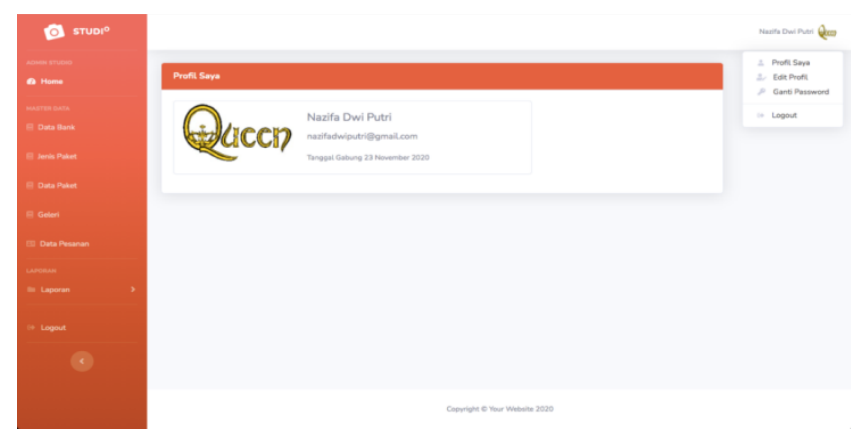

Figure 16. The main page of the Studio Admin

Based on Figure 12, the main studio admin page displays menu options, namely home, bank data, package types, package data, gallery, studio order data, customer data, edit profiles and change passwords.

a. Menu Data Bank

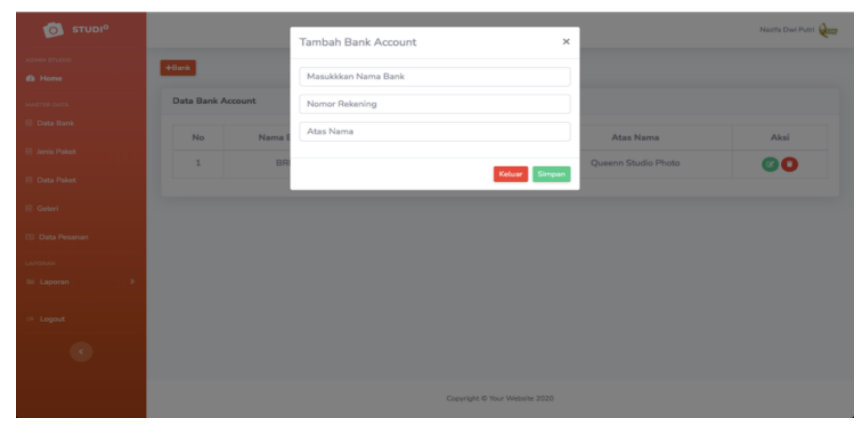

Figure 17. Add Bank Account

The page above is used to add the studio's bank data, which will later be used as a bank transfer option when the customer wants to place an order. The data that the studio admin has entered is stored in the database, and the data will appear.

b. Package Type Menu

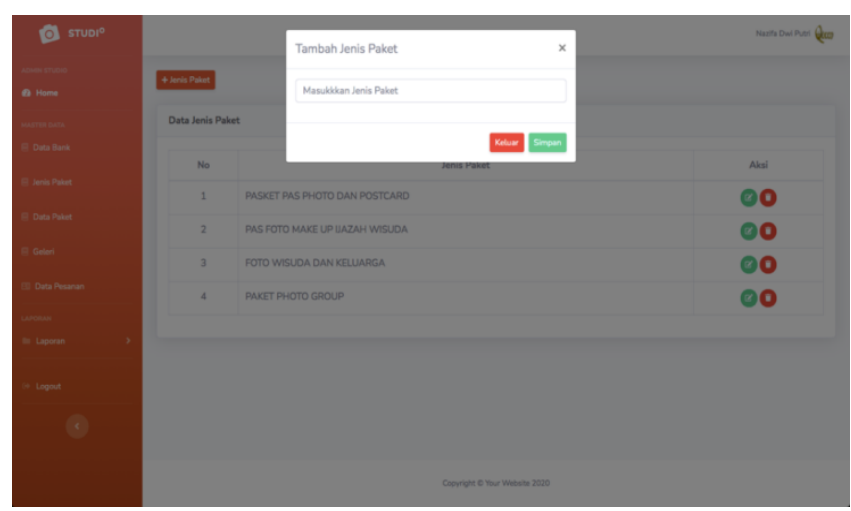

Figure 18. Add-Type of Package

The page above is used to add data on the type of package provided by the studio. The data that the studio admin has entered is stored in the database, and the data will appear.

\section{CONCLUSION}

The conclusions that can be drawn from the Photo studio Marketplace Design in Padang City using a CodeIgniter framework are as follows:

1. This final project produces a photo studio marketplace in the city of Padang as a media for promotion and order to recognize it.

2. With the photo studio marketplace in Padang, customers can order photography services safely and comfortably, and customers can see the available packages.

3. Customers can provide fast service. Namely, customers no longer need to come to the photo studio location because orders can be made online.

4. Customers can download the photos that the photo studio admin has uploaded.

\section{REFERENCES}

[1] A. G. Mario, "Implementasi Ueq Pada Website Marketplace Penyedia Jasa Perbaikan Elektronik," Repos. STMIK Sumedang, 2020, [Online]. Available: https://repository.stmiksumedang.ac.id/index.php/repo/article/view/3 4.

[2] A. Komaruddin, B. Susilo, and ..., "Perancangan Sistem Rekomendasi Pemilihan Cinderamata Khas Bengkulu Berbasis E-Marketplace," Rekursif J. ..., 2019, [Online]. Available: https://ejournal.unib.ac.id/index.php/rekursif/ article/view/6132. 
[3] E. A. Pratama, C. M. Hellyana, and ..., "Pengembangan E-Marketplace Terkoneksi Aplikasi Whatsapp Pada Pasar Muslim Info Kajian Purwokerto (IKP)," J. MEDIA ..., 2020, [Online]. Available: http://ejurnal.stmikbudidarma.ac.id/index.php/mib/article/view/2 381.

[4] I. P. Irwansyah, "Sistem Informasi Akademik Subsistem Master Data Mahasiswa Dengan Menggunakan Framework CodeIgniter," J. Inform., 2018, [Online]. Available: https://pdfs.semanticscholar.org/e805/c68d42f 6382c6c4da5d3540d843e8af62295.pdf.

[5] A. Prihantara and A. Aziz, "Sistem Informasi Pengurusan Surat Pengantar Berbasis Framework Codeigniter Guna Meningkatan Kualitas Pelayanan kepada Masyarakat," J. Inform., 2018, [Online].

[6] I. Sofiani, "Rancang Bangun Aplikasi EMarketplace Hasil Pertanian Berbasis Website Dengan Menggunakan Framework Codeigniter," J. Manaj. Inform., 2019, [Online]. Available: https://ejournal.unesa.ac.id/index.php/jurnalmanajemen-informatika/article/view/31228.

[7] A. Aziz, A. Rohman, and D. Kusumoaji, "Sistem Dokumentasi Rancang Bangun Pesawat Udara Berbasis Web Menggunakan Framework CodeIgniter dan PostgreSQL dengan Metode Prototype," J. Inform. ..., 2020, [Online]. Available: http://repositori.lapan.go.id/60/.

[8] A. GEA, "Implementasi E-Commerce Pada Perancangan Marketplace Guru Private Dengan Model Appreciative Inquiry Berbasis Web," J. Ilm. KOHESI, 2019, [Online]. Available: https://kohesi.sciencemakarioz.org/index.php/J IK/article/view/79.

[9] S. Abdy and M. Alda, "Perancangan Sistem Informasi Apotek Dengan Menggunakan Framework CodeIgniter Dan Database MySQL," J. Inf. Komput. Log., 2020, [Online]. Available: http://ojs.logika.ac.id/index.php/jikl/article/vie $\mathrm{w} / 54$.

[10] M. Nuraminudin, "Implemetasi Teknik Hybrid Mobile Application Dalam Pembuatan Aplikasi Mobile Marketplace Ikan Hias," INFOS JournalInformation Syst. J., 2019, [Online]. Available: https://ojs.amikom.ac.id/index.php/INFOSJourn al/article/view/2422.

[11] W. S. Dharmawan and A. Ardiyansyah, "Pemanfaatan Framework Codeigniter Dalam Pembuatan Sistem Informasi Bimbel Bahasa Inggris Berbasis Web," J. Sist. ..., 2021, [Online]. Available: https://www.ejurnal.stmikbudidarma.ac.id/index.php/JSON/article/view/ 3611.

[12] N. Hayati, I. Irmawati, T. Himawan, and ..., "Perancangan Sistem E-Marketplace Untuk Produk Khas Betawi Dari Jakarta (studi kasus:
Setu Babakan)," JMM-Jurnal ..., 2019, [Online]. Available:

http://jmm.unmerpas.ac.id/index.php/jmm/arti cle/view/21.

[13] Y. Putra and A. Hidayati, "The implementation of restful web services into marketplace generator," J. Phys. Conf. Ser., 2019, doi: 10.1088/17426596/1193/1/012005.

[14] A. Haryati, Perancangan E Commerce Subang Makeup Store Mengunakan Framework Codeigniter. unisbank.ac.id, 2020.

[15] M. Ilmi, D. L. Said, and A. Hadi, “... Sistem Informasi Pernikahan Dan Status Pernikahan Kantor Urusan Agama Kecamatan Canduang Agam Berbasis Web Dengan Framework Codeigniter," Voteteknika (Vocational Tek. ..., 2018, [Online]. Available: http://ejournal.unp.ac.id/index.php/voteknika/ article/view/5849. 